\title{
PRODUCT OF SERUM CALCIUM AND PHOSPHORUS (CaXP) AS A PREDICTOR OF CARDIOVASCULAR DISEASE RISK IN PATIENTS WITH CHRONIC KIDNEY DISEASE
}

\author{
Rojina Bakhunchhen, ${ }^{1}$ Raju Kumar Dubey, ${ }^{2}$ Archana Jayan, ${ }^{2}$ Santosh Kumar Shah, ${ }^{3}$ Prabin Khatri ${ }^{4}$
}

\begin{abstract}
INTRODUCTION

Most of the chronic kidney disease (CKD) patients develop cardiovascular disease (CVD) in their later stages. Various traditional CVD risk factors are highly prevalent in CKD but mortality of these patients cannot be fully justified by these CVD markers. So this study was designed to determine serum calcium and phosphorus product $\left(\mathrm{Ca} \times \mathrm{P}_{\mathrm{i}}\right)$ to predict CVD risk in CKD patients.
\end{abstract}

\section{MATERIAL AND METHODS}

We followed the guidelines of NKF-KDOQI for CKD diagnosis and staging. Further the patients were classified into 3 different groups based on $\mathrm{Ca} \times \mathrm{P}_{\mathrm{i}}$ product; $<40 \mathrm{mg}^{2} / \mathrm{dl}^{2}$ (group 1), $40-55 \mathrm{mg}^{2} / \mathrm{dl}^{2}$ (group 2) and $>55 \mathrm{mg}^{2} / \mathrm{dl}^{2}$ (group 3). We then evaluated CVD risk by various traditional risk factors like age, BMI, BP, smoking history, dyslipidemia, previous history of CVD, LVH, arrhythmia, VHD, cardiomyopathy, and IHD.

\section{RESULTS}

Higher level of $\mathrm{Ca} \times \mathrm{P}_{\mathrm{i}}$ was associated with presence of $\mathrm{LVH}(32.30 \%$ in group $1,31.42 \%$ in group 2 and $46.66 \%$ in group 3), Arrythemia (13.84\% in group 1, 28.57\% in group 2 and $46.67 \%$ in group 3), VHD (5.71\% in group 2 and $10.00 \%$ in group 3), Cardiomyopathy (1.53\% in group 1, 8.57\% I group 2 and $6.66 \%$ in group 3), IHD (6.15\% in group $1,11.42 \%$ in group 2 and $13.33 \%$ in group 3 ) and hypercholesterolemia, hypertriglyceridemia and increased LDLc.

\section{CONCLUSION}

This study found that higher $\mathrm{Ca} \times \mathrm{P}_{\mathrm{i}}$ increases with decline in glomerular filtration rate (GFR) and associated with CVD risks and CVD. So, this study raise a potential need to evaluate the level of calcium and phosphorus in all CKD patients and the level should be monitored more thoroughly to prevent CVD.

KEYWORDS Ca $\times \mathrm{P}_{\mathrm{i}}$ product, Chronic kidney disease, Cardiovascular disease

1. Department of Clinical Laboratory Services, Patan Academy of Health Sciences, Lalitpur, Nepal

2. Department of Biochemistry, Universal College of Medical Sciences, Bhairahawa, Nepal

3. Department of Biochemistry, Janaki Medical College, Janakpur, Nepal

4. Department of Internal Medicine, Universal College of Medical Sciences, Bhairahawa, Nepal

DOI: http//doi.org/10.3126/jucms.v8i1.29829

For Correspondence

Raju Kumar Dubey

Department of Biochemistry

Universal College of Medical Sciences,

Bhairahawa, Nepal

Email: rajukd85@gmail.com 


\section{INTRODUCTION}

Chronic kidney disease (CKD) is worldwide health problem. In Nepal approximately $10 \%$ of the population has CKD and it continues to increase. ${ }^{1}$ The NKF-KDOQI guidelines for CKD state that patients with CKD should be considered in the highest risk group for cardiovascular disease (CVD). ${ }^{2}$ Majority of the patients in the advance stage of CKD develops CVD and it remains the major mortality risk in dialysis patients accounting for almost $50 \%$ of deaths. ${ }^{3,4}$ The mortality rate of CKD patients cannot be fully justified by traditional CVD risk factors like older age, diabetes mellitus, systolic hypertension, and low high density lipoprotein (HDL) which are highly prevalent in CKD. ${ }^{5}$ There has been increasing concern of novel risk factors such as homocysteinemia, elevated inflammatory markers, oxidative stress, dyslipidemia and calcium and phosphorus product for CVD in $\mathrm{CKD}^{5-7} \mathrm{NKF}-\mathrm{KDOQI}$ guideline has recommended $\mathrm{CaxP}_{\mathrm{i}}$ to maintain below $55 \mathrm{mg}^{2} / \mathrm{dl}^{2}$ in $\mathrm{CKD}$ cases. ${ }^{2}$ Elevated $\mathrm{CaxP}_{\mathrm{P}}$ products are associated with cardiovascular calcification. ${ }^{7,8}$ Since CKD is associated with disruption of the endocrine system that distorts the balance between calcitriol, calcium, phosphorus and parathyroid hormone which in turn affects bone mineral density leading to mineral bone disorder, $\mathrm{CaxP}_{\mathrm{i}}$ could be good marker to predict CVD in patients with CKD. Thus we aimed to examine the relationship between $\operatorname{CaxP}_{\mathrm{i}}$ and CVD and its risk in renal failure patients.

\section{MATERIAL AND METHODS}

This hospital based cross-sectional study was conducted at Universal College of Medical Sciences, Bhairahawa, Nepal from January 2016 to June 2016. Total of 130 patients diagnosed with CKD was recruited in this study by using consecutive sampling technique. We followed the guidelines of NKF-KDOQI for CKD staging. ${ }^{2}$ We excluded the patients suffering from other chronic diseases such as tuberculosis, COPD, cancer and patients previously diagnosed with CVD. Pregnant women, pediatric patients and critically ill patients were excluded in the study. The study was approved by Institutional Review Committee and patients were informed about the study. We recorded data for anthropometric and clinical history. We also obtained the data of electro cardiogram (ECG) from the participants. Fasting blood sample was taken for the analysis of biochemical parameters. Patients were classified into three different groups based on the levels of CaxP ; Group $1\left(<40 \mathrm{mg}^{2} / \mathrm{dl}^{2}\right)$, Group $2(40-55$ $\left.\mathrm{mg}^{2} / \mathrm{dl}^{2}\right)$ and Group $3\left(>55 \mathrm{mg}^{2} / \mathrm{dl}^{2}\right)$. Among all the renal failure patients, $13.84 \%, 40.76 \%$ and $45.38 \%$ were from stage 3,4 and 5 CKD respectively. Glomerular filtration rate (eGFR) was estimated by Cockroft and Gault formula. ${ }^{9}$ We evaluated CVD risk by various traditional risk factors like age, body mass index (BMI), blood pressure (BP), smoking history, dyslipidemia, previous history of CVD, left ventricular hypertrophy (LVH), arrhythmia, valvular heart disease
(VHD), cardiomyopathy, and ischemic heart disease (IHD). Data were analyzed by SPSS version 22.0 (SPSS Inc, USA). Categorical variables were presented as number and percentage and compared by Chi-square test. Continuous data were expressed as mean \pm standard deviation (SD). One way analysis of variance (ANOVA) was applied to compare means. Multiple regression analysis was used to determine the Odds ratio and relative risk. The level of significance was set at $\mathrm{p}<0.05$.

\section{RESULTS}

Out of 130 CKD patients, $62.30 \%$ (81) was male and $37.69 \%$ (49) was female. Based on smoking habit, majority of the patients were past smokers $67.69 \%$ (88), followed by non smokers 23.07\% (30), and current smokers 9.23\% (12). Similarly based on alcohol intake, $14.62 \%$ (19), 20\% (26), and $65.38 \%$ (85) were non-alcoholic, past-alcoholic and current alcoholic respectively. When we evaluated the participants based on the $\operatorname{CaxP}_{\mathrm{i}}$ levels, half $(50 \%)$ of the CKD cases belonged to Group 1, followed by group 2 (27\%) and group 3 $(23 \%)$.

Table 1 shows the characteristics of CKD patients in three different groups of $\mathrm{CaxP}_{\mathrm{i}}$. Serum urea and creatinine levels were found to increase with highest value in group 3. Similarly LDLc level was the highest in group 3 as compared to group 2 and group 1. eGFR was found to decrease with increase in the levels of $\mathrm{CaxP}_{\mathrm{i}}$.

Table 1. General characteristics of patients in different $\mathrm{Ca} \times \mathrm{P}_{\mathrm{i}}$ groups

\begin{tabular}{|c|c|c|c|c|}
\hline Parameters & $\begin{array}{c}\text { Group1 } \\
\left(\mathrm{Ca} \times \mathrm{P}_{\mathrm{i}}<40 \mathrm{mg}^{2} / \mathrm{dl}^{2}\right)\end{array}$ & $\begin{array}{c}\text { Group2 } \\
\left(\mathrm{Ca} \times \mathrm{P}_{\mathrm{i}} 40-\right. \\
\left.55 \mathrm{mg}^{2} / \mathrm{dl}^{2}\right)\end{array}$ & $\begin{array}{c}\text { Group3 } \\
\left(\mathrm{Ca} \times \mathrm{P}_{\mathrm{i}}>55 \mathrm{mg}^{2} / \mathrm{dl}^{2}\right)\end{array}$ & p-value \\
\hline Age (yr) & $55.87 \pm 13.42$ & $48.43 \pm 20.31$ & $60.23 \pm 19.53$ & 0.006 \\
\hline BMI $\left(\mathrm{kg} / \mathrm{m}^{2}\right)$ & $28.44 \pm 4.40$ & $28.10 \pm 4.78$ & $27.02 \pm 4.54$ & 0.36 \\
\hline SBP (mmHg) & $128.31 \pm 23.82$ & $134.87 \pm 25.48$ & $126.33 \pm 22.20$ & 0.29 \\
\hline DBP (mmHg) & $79.54 \pm 12.92$ & $80 \pm 15.52$ & $77 \pm 16.22$ & 0.66 \\
\hline Urea (mg/dl) & $130.6 \pm 57.58$ & $128.2 \pm 49.60$ & $171.5 \pm 61.04$ & 0.002 \\
\hline Creatinine (mg/dl) & $4.99 \pm 6.07$ & $5.0 \pm 2.67$ & $7.67 \pm 4.94$ & 0.04 \\
\hline Calcium (mg/dl) & $8.51 \pm 1.89$ & $8.97 \pm 1.53$ & $10.09 \pm 2.41$ & 0.002 \\
\hline Phosphorus (mg/dl) & $3.58 \pm 1.21$ & $5.28 \pm 1.01$ & $7.4 \pm 2.00$ & 0.001 \\
\hline $\mathrm{Ca} \times \mathrm{P}_{\mathrm{i}}\left(\mathrm{mg}^{2} / \mathrm{dl}^{2}\right)$ & $29.02 \pm 7.10$ & $46.24 \pm 4.50$ & $72.05 \pm 16.25$ & 0.001 \\
\hline $\mathrm{TC}(\mathrm{mg} / \mathrm{dl})$ & $140.14 \pm 44.03$ & $154.15 \pm 57.62$ & $165.07 \pm 53.10$ & 0.69 \\
\hline HDLc (mg/dl) & $32.66 \pm 10.12$ & $33.45 \pm 11.09$ & $33.65 \pm 10.73$ & 0.89 \\
\hline $\mathrm{TG}(\mathrm{mg} / \mathrm{dl})$ & $155.55 \pm 59.80$ & $148.53 \pm 73.69$ & $149.1 \pm 45.99$ & 0.82 \\
\hline $\operatorname{VLDLc}(\mathrm{mg} / \mathrm{dl})$ & $31.11 \pm 11.96$ & $29.70 \pm 14.73$ & $29.82 \pm 9.1$ & 0.82 \\
\hline LDLc (mg/dl) & $76.36 \pm 38.16$ & $90.99 \pm 55.24$ & $101.62 \pm 48.45$ & 0.03 \\
\hline eGFR (ml/min) & $20.75 \pm 10.87$ & $19.15 \pm 11.04$ & $13.40 \pm 10.16$ & 0.009 \\
\hline
\end{tabular}


Figure 1 shows the number of cases with various types of CVD in three different groups of $\mathrm{CaxP}_{\mathrm{i}}$. In general it was found that the incidence of CVD diseases increases with increase in $\mathrm{CaxP}_{\mathrm{i}}$ level. Chi-square analysis showed significant association between $\operatorname{CaxP}_{\mathrm{i}}$ and arrhythmia $(\mathrm{p}=0.003)$, VHD $(p=0.05)$. However LVH $(p=0.38)$, cardiomyopathy $(p=0.14)$ and $\operatorname{IHD}(\mathrm{p}=0.46)$ did not show any association with $\mathrm{CaxP}_{\mathrm{i}}$.

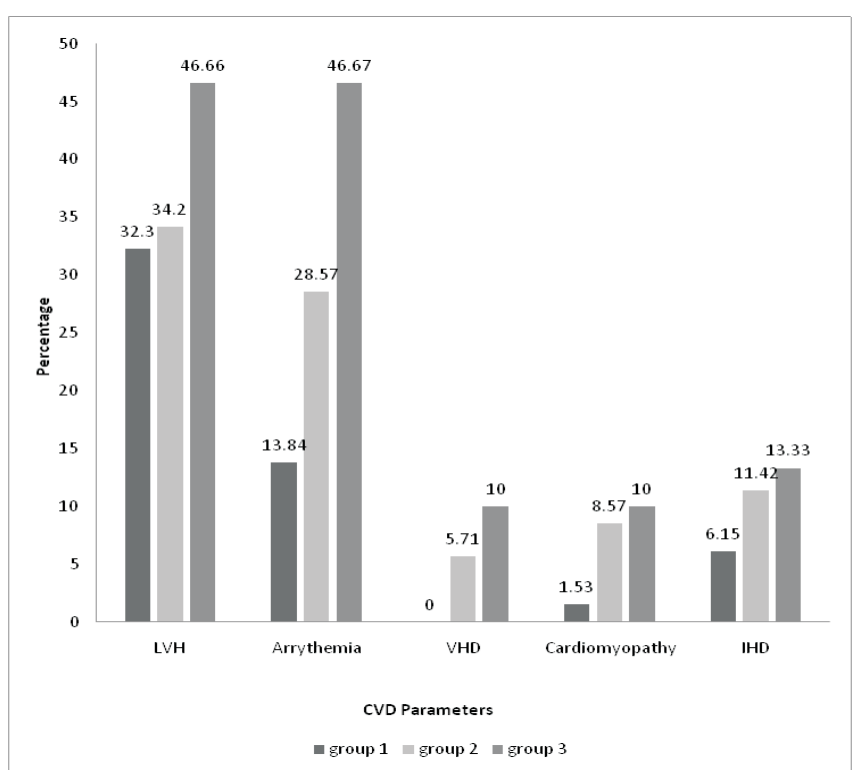

Figure 1. Number of cases with various types of CVD in three different $\mathrm{Cax}_{\mathrm{i}}$ groups.

Table 2 shows the categorization of the patients based on their lipid level in three different groups. We found that the number of the patients in these groups increases with increase in the level of TC (3.1\% vs $5.7 \%$ vs $6.7 \%)$ and LDLc ( $0 \%$ vs $8.5 \%$ vs $10 \%)$. In contrast, the number of the patients decreases in these groups with increasing level of HDLc (7.6\% vs 5.7\% vs $3.3 \%$ ).

Table 2. Distribution of patients based on lipid level in different $\mathrm{Ca} \times \mathrm{P}_{\mathrm{i}}$ Groups

\begin{tabular}{ccccc}
\hline \multirow{2}{*}{ Lipid profile } & Range $(\mathrm{mg} / \mathrm{dl})$ & \multicolumn{3}{c}{ N $(\%)$} \\
\cline { 3 - 5 } & & Group 1 & Group 2 & Group 3 \\
\hline \multirow{3}{*}{ TC } & $<200$ & $60(92.3)$ & $29(82.8)$ & $20(66.6)$ \\
& $200-239$ & $3(4.6)$ & $4(11.4)$ & $8(26.6)$ \\
& $\geq 240$ & $2(3.1)$ & $2(5.7)$ & $2(6.7)$ \\
\hline \multirow{2}{*}{ TG } & $<150$ & $32(49.2)$ & $19(54.2)$ & $14(46.6)$ \\
& $150-199$ & $19(29.2)$ & $9(25.7)$ & $10(33)$ \\
& $\geq 200$ & $14(21.5)$ & $7(20)$ & $6(20)$ \\
\hline \multirow{2}{*}{ LDLc } & $<100$ & $51(78.4)$ & $26(74.2)$ & $14(46.6)$ \\
& $100-129$ & $7(10.7)$ & $2(5.7)$ & $6(20)$ \\
& $130-159$ & $5(7.7)$ & $3(8.5)$ & $5(16.6)$ \\
& $160-189$ & $2(3.1)$ & $1(2.8)$ & $2(6.6)$ \\
& $\geq 190$ & $0(0)$ & $3(8.5)$ & $3(10)$ \\
\hline \multirow{2}{*}{ HDLc } & $<40$ & $43(66.1)$ & $22(62.8)$ & $21(70)$ \\
& $40-59$ & $17(26.1)$ & $11(31.4)$ & $8(26.6)$ \\
& $\geq 60$ & $5(7.6)$ & $2(5.7)$ & $1(3.3)$ \\
\hline
\end{tabular}

CaxP $_{\mathrm{i}}$ was positively correlated with $\mathrm{TC}(\mathrm{r}=0.24, \mathrm{p}=0.005)$, and LDLc $(r=0.26, p=0.002)$. In contrast, eGFR showed negative correlation $(\mathrm{r}=-0.32, \mathrm{p}=0.001)$ with $\mathrm{CaxP}_{\mathrm{i}}$. Multiple regression analysis (Table3) demonstrated that $\mathrm{CaxP}_{\mathrm{i}}$ is an independent predictor for high TC and LDLc in renal failure patients.

\section{Table 3. $\mathrm{Ca} \times \mathrm{P}_{\mathrm{i}}$ as a predictor of lipid disorder}

\begin{tabular}{ccc}
\hline Lipid profile & $\boldsymbol{\beta}$ & $\mathbf{p}$-value \\
\hline TC & 0.124 & 0.002 \\
HDLc & 0.041 & 0.42 \\
TG & 0.006 & 0.915 \\
LDLc & 0.081 & 0.046 \\
\hline
\end{tabular}

\section{DISCUSSION}

We assessed CVD risk based on the level of $\mathrm{Ca} \times \mathrm{P}_{\mathrm{i}}$ in renal failure patients. CVD risk was found to increase with increase in the level of $\mathrm{Ca} \times \mathrm{P}_{\mathrm{i}}$. With increase in the level of $\mathrm{Ca} \times \mathrm{P}_{\mathrm{i}}$, number of CVD patients was also found to be increased; $\mathrm{LVH}$ $(32.30 \%$ vs $34.20 \%$ vs $46.66 \%$ ), arrythemia $(13.84 \%$ vs $28.57 \%$ vs $46.67 \%)$, VHD (0\% vs 5.71 vs $10 \%)$, cardiomyopathy (1.53\% vs 8.57 vs $10 \%)$, and IHD (6.15 vs $11.42 \%$ vs $13.33 \%$ ). Similarly, TC and TG level were found to increase with increase in $\mathrm{Ca} \times \mathrm{P}_{\mathrm{i}}$ level, unlike HDLc level which was found to decrease with increase in the value of $\mathrm{Ca} \times \mathrm{P}_{\mathrm{i}}$. eGFR showed negative correlation with $\mathrm{Ca} \times \mathrm{P}_{\mathrm{i}}(\mathrm{r}=-$ $0.32, \mathrm{p}=<0.001)$.

A similar study by Regmi et $\mathrm{al}^{10}$ found that higher $\mathrm{Ca} \times \mathrm{P}_{\mathrm{i}}$ is associated with presence of $\mathrm{LVH}$, oxidative stress, microinflammation, hyperhomocysteinemia, hypercholesterolemia, hypertriglyceridemia and increased LDLc. In addition, Ganesh et $\mathrm{al}^{7}$ found the progressive association between $\mathrm{CaxP}_{\mathrm{i}}$ and death from coronary artery disease (Relative risk (RR) 1.06) and sudden death (RR 1.07) per 10 $\mathrm{mg}^{2} / \mathrm{dl}^{2}$ increase in $\mathrm{CaxP}_{\mathrm{i}}$. More evidences from Young et $\mathrm{al}^{11}$ and Block et $\mathrm{al}^{12}$ further supported these findings. Young et al demonstrated that $\mathrm{CaxP}_{\mathrm{i}}$ is independent predictor of all-cause and CVD mortality with RR 1.02 and 1.05 per $5 \mathrm{mg}^{2} / \mathrm{dl}^{2}$ increase in the level of $\mathrm{CaxP}_{\mathrm{i}}$ respectively. In a study of Block et al multivariable RR of death associated with $\mathrm{CaxP}_{\mathrm{i}}$ products of 45 to $50 \mathrm{mg}^{2} / \mathrm{dl}^{2}$ and 50 to $55 \mathrm{mg}^{2} / \mathrm{dl}^{2}$ were 1.06 and 1.14 respectively.

Similarly study conducted in Chinese patients with renal insufficiency showed that the CVD risk is significantly increased in patients with CKD. Even minor CKD has a major impact on the CVD risk. ${ }^{13}$ This is further supported by the findings of the study from Kahnooj $\mathrm{M}$ et $\mathrm{al}^{14}$ in which they illustrated that $\operatorname{CaxP}_{\mathrm{i}}$ level more than $42 \mathrm{mg}^{2} / \mathrm{dl}^{2}$ was the optimal value in terms of sensitivity and specificity for 
predicting the presence of vulvular insufficiency. Aortic insufficiency was directly associated with a high $\mathrm{CaxP}_{\mathrm{i}}$ level after adjustment for additional known mortality predictors $\mathrm{p}=0.01$ ). Similarly a study conducted in Polish population also found that $55 \%$ of CKD patients had abnormal left ventricular heart structure. $^{15}$

The serum total $\mathrm{CaxP}_{\mathrm{i}}$ product is an indicator of the risk of calciphylaxis, in particular cardiovascular calcification. The positive balance of this product is mainly due to high bone turnover in CKD which activate vascular smooth muscle cell (VSMC) to differentiate into osteo/chondrocyte-like cells by up regulation of RUNX-2 and MSX-2 transcription factors. These cells form collagen and noncollagenous proteins in the intima or media and incorporate calcium and phosphorus into matrix vesicles to initiate mineralization. ${ }^{16}$ Our study found high levels of calcium and phosphorus. Higher phosphorus levels are associated with coronary artery calcification and vascular stiffness in humans. In in vitro conditions, higher extracellular phosphorus concentrations induce aortic VSMC to transform into osteoblast-like cells and to calcify the vascular extracellular matrix. ${ }^{17}$ Similarly positive calcium balance may also be a factor in the pathogenesis of arterial calcification by altering VSMC functions and affecting NFAT cell signalling. ${ }^{18}$

\section{CONCLUSION}

This study showed that $\operatorname{CaxP}_{\mathrm{i}}$ increases with decrease in GFR and associated with various CVD and CVD risks. So this study raise a potential need to evaluate the level of calcium and phosphorus in all CKD patients and the level should be monitored more thoroughly to reduce morbidity and mortality in these patients due to CVD.

\section{CONFLICT OF INTEREST}

None

\section{REFERENCES}

1. Tsukamoto Y, Wang HY, Becker G, Hen HC, Han DS, Harris D1 Report of the Asian Forum of Chronic Kidney Disease Initiative (AFCKDI). "Current status and perspective of CKD in Asia": diversity and specificity among Asian countries. Clin Exp Nephrol. 2007;13:24956.

2. K/DOQI clinical practice guideline for chronic kidney disease: evaluation, classification and stratification. Kidney Disease Outcome for Quality Initiative. Am J Kidney Dis. 2002;3 (Suppl. 2):S1S246.

3. Lmaden Y, Canalejo A, Ballesteros E. Regulation of arachidonic acid production by intracellular calcium in parathyroid cells: Effect of extracellular phosphate. J Am Soc Nephrol. 2002;13:693-98.

4. Sarnak MJ, Levey AMJ, Levey LS. Epidemiology of cardiac disease in dialysis patients. Semin Dial. 1999;12:69-76.
5. Vlagopoulos PT, Sarnak MJ. Traditional and nontraditional cardiovascular risk factors in chronic kidney disease. Med Clin North Am. 2005;89:587611

6. Kovesdy CP, Kuchmak O, Lu JL, Kalantar-Zadeh K. Outcomes associated with serum calcium level in men with non-dialysisdependent chronic kidney disease. Clin J Am Soc Nephrol. 2010;5:46876

7. Ganesh SK, Stack AG, Levin NW, Hulbert-Shearon T, Port FA. Association of elevated serum PO (4), Ca x PO (4) product, and parathyroid hormone with cardiac mortality risk in chronic hemodialysis patients. J Am Soc Nephrol. 2001;12:213138.

8. Larsson TE, Olauson H, Hagstrom E, Ingelsson E, Arnlov J, Lind L, et al. Conjoint effects of serum calcium and phosphate on risk of total,cardiovascular, and noncardiovascular mortality in the community. Arterioscler Thromb Vasc Biol. 2010;30 :33339.

9. Cockcroft DW, Gault MH. Prediction of creatinine clearance from serum creatinine. Nephron. 1976;16(1):31-41.

10. Regmi P, Malla B, Gyawali P, Sigdel M, Shrestha R, Shah DS, et al. Product of serum calcium and phosphorus $(\mathrm{Ca} \times \mathrm{PO} 4)$ as predictor of cardiovascular disease risk in predialysis patients. Clin Biochem. 2014; 47:77-81.

11. Young EW, Albert JM, Satayathum S, Goodkin DA, Pisoni RL, Akiba T, et al. Predictors and consequences of altered mineral metabolism: the Dialysis Outcomes and Practice Patterns Study. Kidney Int. 2005; 67:117987.

12. Block GA, Klassen PS, Lazarus JM, Ofsthun N, Lowrie EG, Chertow GM. Mineral metabolism, mortality, and morbidity in maintenance hemodialysis. J Am Soc Nephrol. 2004; 15:220818.

13. Hou FF, Ma ZG, Mei CL, Rong S, Huang SM, Liu XR, et al. Cardiovascular disease in Chinese chronic renal insufficiency patients- epidemiology survey. Am J Nephrol .2008; 28:1-7.

14. Kahnooj M, Masoomi M, Nadarinasab A, Zaeem A, Sheikhvatan M. Relationship between calcium-phosphorus product and severity of Vulvular heart insufficiency in patients undergoing chronic dialysis. J Tehran Heart Cent. 2010;5(2):7882

15. Strózecki P, Kozłowski M, Grajewska M, Kurowski R, Stefańska A, Odrowaź-Sypniewska G, et al. Cardiovascular system in patients in different stages of chronic kidney disease. Pol MerkurLekarski. 2006; 21(122):125-29.

16. Moe SM, Chen NX. Mechanisms of vascular calcification in chronic kidney disease. J Am Soc Nephrol .2008; 19(2):213-16.

17. Jono S, Mckee MD, Murry CE, Shioi A, Nishizawa Y, Mori K, et al. Phosphate regulation of vascular smooth muscle cell calcification. Circ Res. 2000; 87(7):E10-17.

18. Moe SM. Calcium as a cardiovascular toxin in CKD-MBD. Bone. 2017; 100:94-99. 